presented in different media (newspapers, cinema, magazines, comics). The author shows how cinema affected the story paper narrative (use of cliff-hangers) and style (cinematic speed in the succession of action events) and ultimately led to its final decline. Fairlie sees this field of entertainment production for children as a constant competition in which story papers eventually lose the battle (story papers disappeared by the 1960s) (187) against the strong appeal of visual (cinema) and multimodal (comics) storytelling.

The theoretical approaches of new historicism and cultural materialism make it possible for this study to view the story paper genre in a completely new way. For the study of children's literature, this research is valuable from several viewpoints: it shows how these entertaining and, for children, affordable narratives excluded adults from the authortext-reader communication and turned children into consumers (of different kinds of goods as well), and how other mass media brought a change of style and narrative construction to the school story genre (I assume this influence may have a much broader application). Finally, it tries to construct an image of childhood leisure experience in reading story papers in the period between the two world wars. In this way, this study can certainly contribute to developing a new perspective on the history of children's literature.

Sanja Lovrić Kralj

\title{
SuperDahl: Literature, Criticism and Paratext
}

Laura Viñas Valle. 2016. De-constructing Dahl. Cambridge: Cambridge Scholars Publishing. 191 pp. ISBN: 978-1-4438-8258-3

DOI: 10.21066/carcl.libri.2016-05(02).0011

The book De-constructing Dahl by Laura Viñas Valle, published by Cambridge Scholars Publishing in 2016, is an academic study of the children's literary works of Roald Dahl from the point of view of socio-cultural constructivist theory, and the first singleauthored monograph on Roald Dahl since 1994. The long list of sources, acknowledgments and references is proof that the author spent a substantial amount of time immersed in research on this famous, highly complex and controversial author in an attempt to subject Dahl "to a de-constructing process which has entailed analysing the assumptions that underpin claims made about 'children', 'childhood' and 'children's literature'” (165).

Accordingly, the book is divided into three chapters which landmark the authorial process of de-construction. The author claims that despite Dahl's popularity, there is not much scholarly work available on his writing and lists three existing book-length studies: Alan Warren's Roald Dahl: From the Gremlins to the Chocolate Factory (1988), Mark I. West's Roald Dahl (1992), and the essay collection Roald Dahl (2012) edited by Catherine Butler and Ann Alston. These are outnumbered by several biographies on Dahl, written by Chris Powling (1985), Jeremy Treglown (1994), Jennet Conant (2008), Donald Sturrock (2010) and Michael Rosen (2012). The book De-constructing Dahl is therefore an attempt to review, complement and contextualise the exploration of Dahl from a multitude of perspectives.

In the first chapter, "De-constructing Dahl through Criticism", Viñas Valle provides a thorough overview of the criticism and reception of Dahl's work within the context of a variety of literary and cultural theories. The overview addresses text-based approaches to 
children's literature that emerged in the 1990s, as well as traditional approaches derived from educational studies, librarianship and reader-response criticism. The chapter focuses on the striking features and appeal of Dahl's writing in terms of memory, observation, or identification, and in particular on an examination of studies on Charlie and the Chocolate Factory (1964) and Matilda (1988). Provided in this chapter is a detailed account of the plurality of critical voices which mark the mixed reception of Roald Dahl's children's books, as well as what is known of his influence and legacy.

This overview of the literary and cultural significance of Roald Dahl is followed by the chapter "De-constructing Dahl's Children's and Adult Books", in which the author presents the reader with her own analysis of the particular ingredients of Roald Dahl's writing. By discussing Dahl's narrative voice, characterisation in terms of names and surnames, physical or character attributes, bodily functions - a.k.a. "the pleasures of orality and anality" (94) - and conflicts of power in both his children's books and fiction for adults, Viñas Valle pinpoints some of the defining characteristics of Dahl's style, and attempts to "dismantle the idea that Dahl is a two-headed writer whose children's and adult books belong to two distinct separate literary fields with nothing or little in common between the two" (166). Quite inconveniently, however, the author was not granted permission from the Roald Dahl Literary Estate to reproduce quotes from Dahl's literary works or his editorial correspondence in Chapter Three, which affects the overall flow, impact and stylistic opulence of the text.

Finally, in Chapter Three, the author places Roald Dahl in context by focusing on paratexts, elaborated in Gérard Genette's 1987 study Paratexts: Thresholds of Interpretation (published in English in 1997), and observes Dahl in the public and private spheres pertaining to epitexts (his writing hut, his "SuperDahl figure", his editorial correspondence), and peritexts, such as the Dahl-Blake partnership or the classification of his works in terms of his target audience, marketing and design, all of which "make up the packaging of 'Dahl"" (4).

As an extension of her doctoral dissertation "Constructing Dahl: A Reappraisal of Roald Dahl's Children's Books" (Universidad Autónoma de Madrid, 2004) which was followed by years of research, as well as a personal battle to overcome a serious illness, this book is Laura Viñas Valle's attempt at portraying "her Dahl" as a representation of her own practice in reading, interpreting and researching children's literature, as stated in the Epilogue. For this reason, the focus is on Dahl's work as literature. Furthermore, as a Spanish native speaker, the author speaks from within a culture which has, from a critical perspective, always favoured Dahl, while her analysis is also based on her research conducted in the UK. At the same time, she discusses the relatively small output of research on Dahl's work, predominantly available in English-speaking countries. While this book does not provide an answer or any groundbreaking theory on Dahl's literary creation, it does outline key issues and considerations attributed to his fiction, and provides an overview of the perspectives, theories and approaches to childhood, children's literature, and children's culture.

Although we might never resolve the enigma of Dahl, his mind, his mastery of language, or the fact that he probably would have considered any academic research on his opus sheer idiocy, we should certainly be grateful for worthy contributions such as 
De-constructing Dahl by Laura Viñas Valle. It is a valuable and detailed resource which examines Dahl in a social, cultural and literary context, but which also sheds some light on the contents of Dahl's hut, what went on in there, and why it delights us so much.

Željka Flegar

\section{Multiple Interactions}

\section{John A. Bateman. 2014. Text and Image: A Critical Introduction to the Visual/ Verbal Divide. London: Routledge. 276 pp. ISBN: 978-0-415-84198-6 \\ DOI: $10.21066 /$ carcl.libri.2016-05(02).0012}

In today's digital environment, the commonplace practice of combining text with image is transforming and adopting new flexible forms, a process which provokes scholars to develop approaches for understanding these notions and how they work together to create new meanings. However, as different disciplines approach the subject, they also offer different perspectives and the "text-image divide" is still present. In his book Text and Image: A Critical Introduction to the Visual/Verbal Divide, John A. Bateman aims to relate these different approaches and establish a common ground for research on this subject. It is an introductory textbook for the interdisciplinary study of multimodality and the text-image relationship which provides a detailed overview of approaches dealing with text, image and their combinations, such as socio-semiotics, visual communication, psycholinguistic approaches to discourse, rhetorical approaches to advertising and visual persuasion, and cognitive metaphor theory. The author highlights the strengths and weaknesses of each approach, outlines questions for further research, and finally proposes a new multimodal framework for the study and interpretation of meanings produced by the text-image interaction/combination.

The book is divided into three parts consisting of five modules, each representing a different aspect of the text-image relation, and fourteen units. The first part of the book, "Relating Text and Image", focuses on the definition of "text" and "image", and the meaning multiplication which occurs when these two distinct modalities of information presentation are used together: "the meanings of one and the meanings of the other resonate so as to produce more than the sum of the parts" (6). Although some text-image combinations are straightforward and easy to interpret, some are more complex and require a more systematic approach. Hence, the author emphasises the need for research on text-image relations and the importance of multimodal literacy in our digital, multimodal climate. In Unit 2, the author presents a historical overview of scholarly investigation of text-image relations, pointing out the contributions of Roland Barthes, whose early work presents a starting point in the study of text-image relationships.

Part 2, "Visual Contexts", consists of two modules and is concerned with contexts, such as picturebooks, comics and advertisements, in which text and image coexist, providing new possibilities of meaning.

In Module 2, "Visual Narratives", the author suggests that the constructs used for exploring and describing narratives can also be employed in investigating visual communication and visual narratives, which he then exemplifies in the analysis of 